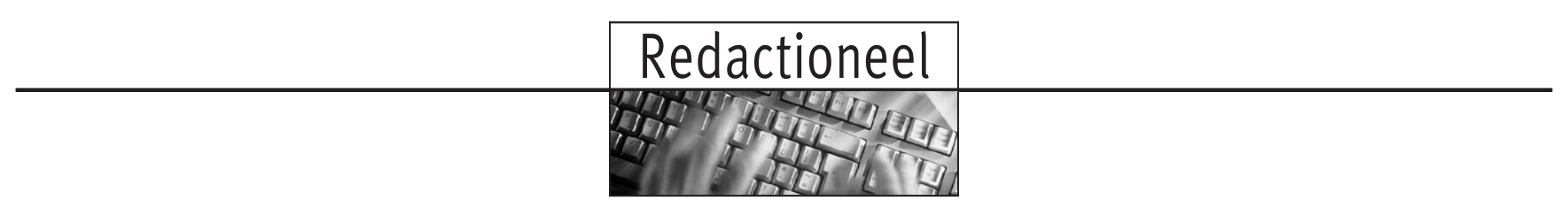

\title{
Investeren in een gezonde omgeving
}

De public health houdt zich onder meer bezig met het creëren van een gezonde omgeving die het mensen mogelijk maakt om gezonde keuzes te maken. Een gezonde omgeving, zoals schone lucht in woonwijken ver van snelwegen, kan de gezondheid van een individu direct beïnvloeden. Ook maatregelen in de omgeving die mensen tot gezond gedrag bewegen, zoals een rookverbod op het werk of in de horeca, leiden indirect tot een betere gezondheid. Een gezonde omgeving kan worden gezien als een elixer die extra kracht geeft aan het verbeteren van de gezondheid van mensen. Met verstandige omgevingsmaatregelen kan veel gezondheidswinst worden bereikt. Denk bijvoorbeeld aan verbeterde hygiëne, frisse lucht, gezonde (baby)voeding, en de start van consultatiebureaus (vaccinaties), waarmee de hoge kindersterfte in de vorige eeuw omlaag is gebracht. Deze voorbeelden maken duidelijk dat het samenspel van een gezonde omgeving, de beschikbaarheid van een goede zorgstructuur en effectieve strategieën van gedragsbeïnvloeding het succes van public health bepalen.

In de vorige kabinetsperiode verslapte de aandacht voor dit samenspel van public health activiteiten. Alleen voor het bevorderen van de gezondheid van jongeren zag de vorige regering een rol voor zichzelf weggelegd. Het kabinet Rutte-Asscher lijkt te breken met het beleid dat de verantwoordelijkheid voor het maken van gezonde keuzes geheel bij de burger legde. In het nieuwe regeerakkoord 'Bruggen slaan' ${ }^{1}$ schrijven de coalitiepartijen opnieuw dat mensen zelf verantwoordelijk zijn voor preventie en een gezonde leefstijl, maar ze voegen daaraan toe: "wij willen dit ondersteunen". De toevoeging van dit ene zinnetje geeft het veld van public health de hoop dat de burger er niet alleen voor staat in zijn pogingen om gezond te leven. Ook de samenleving is verantwoordelijk voor omstandigheden die gezond leven mogelijk maken. De regering erkent daarmee de noeste arbeid die de public health in Nederland verricht om een gezonde omgeving te creëren en de volksgezondheid in Nederland op een goed peil te houden.

Stivoro waarschuwde onlangs dat het aantal rokers toeneemt. Als verklaring werd de laissez faire houding van het vorige kabinet aangevoerd. Veel goede maatregelen werden van de ene op de andere dag teruggedraaid: medicijnen die helpen bij stoppen met roken werden niet meer vergoed, publiekscampagnes werden stopgezet en in delen van de horeca werd roken weer toegestaan. Een eigenschap van preventie is dat effecten van maatregelen niet altijd zichtbaar zijn. Maar worden maatregelen die roken tegengaan afgeschaft, dan komen de negatieve gevolgen voor de volksgezondheid prompt tevoorschijn. Het beschermen en bevorderen van volksgezondheid werkt alleen bij een niet aflatende aandacht voor een gezonde omgeving, het organiseren van een goed zorgsysteem en het veranderen van risicogedrag in de bevolking. De uitgevaardigde rook- en verkoopverboden hebben tot een duidelijke trend geleid van minder roken in de bevolking in de afgelopen tien jaar. Zo bleek onlangs dat het aantal vrouwen dat rookt tijdens de zwangerschap in de laatste tien jaar is gehalveerd. ${ }^{2}$ Voor de keuze om niet te roken is de burger zelf verantwoordelijk, maar de overheid kan het gezonde gedrag inderdaad ondersteunen.

Werd vroeger verontreinigd drinkwater als belangrijke bedreiging gezien voor de volksgezondheid, nu is het drinken van gezoete frisdranken een bedreiging voor het ontstaan van overgewicht en obesitas met chronische ziekten tot gevolg. Ook hier kunnen omgevingsmaatregelen gezondheidsbedreigingen tegengaan. Bijvoorbeeld meer caloriearme frisdranken of water aanbieden in automaten op middelbare scholen, leidt tot consumptie van de gezondere producten uit de automaat. Hetzelfde geldt voor het gezonder maken van de snoepautomaten op scholen. Wanneer de school ook nog het beleid heeft dat jongeren niet het schoolplein af mogen, dan kopen zij vaker de beschikbare gezonde producten op school. ${ }^{3}$ Deze omgevingsmaatregelen kunnen scholen morgen al invoeren, maar dan moeten zij wel actief worden gestimuleerd om bij te dragen aan het indammen van de obesitasepidemie. Een gezonde omgeving helpt niet alleen jongeren bij het maken van gezonde keuzes. Ook volwassenen kunnen een steuntje in de rug gebruiken om de gezonde keuze te maken en de verlokkingen van zoete en vette extra's te weerstaan.

De noodzaak van niet aflatende aandacht voor volksgezondheidsproblemen kan duidelijk worden gemaakt met het eerdergenoemde voorbeeld van kindersterfte aan het begin van de vorige eeuw. Anno 2013 zijn nog steeds verbeteringen in het zorgsysteem nodig, maar ook voorlichting in de zorg over onder andere roken tijdens de zwangerschap om de perinatale sterfte omlaag te brengen. De public health sector is nooit klaar met zijn taak de volksgezondheid te beschermen en bevorderen. Krachtdadig regeringsbeleid is nodig om omgevingsverandering, zorgverbetering en gedragsveranderingsstrategieën in maatregelen of wetten vast te leggen en te voorzien in noodzakelijke financiële prikkels. Het kabinet kiest in het regeerakkoord voor het ondersteunen van de burger bij een gezonde leefstijl. Het kondigt afspraken hierover aan met de zorgverzekeraars. De minimumleeftijd voor alcoholverstrekking wordt verhoogd naar 18 jaar. Dit gaat vergezeld met voorlichting en handhaving. Verder gaan de accijnzen van alcohol en tabak omhoog, waarschijnlijk vooral omdat dit goed is voor de staatskas, maar het is 
óók gunstig voor preventie. Een eerste succes van het nieuwe kabinet is de bereidheid van tabaksfabrikanten om mee te werken aan verhoging van de leeftijdsgrens voor tabaksverkoop naar 18 jaar. Hiermee willen de fabrikanten mogelijk nieuwe, voor hen ongunstige, beleidsmaatregelen voor zijn. Preventie lijkt weer te mogen, gezien dit pakket aan omgevingsmaatregelen die mensen, en zeker ook jongeren, moeten bewegen tot gezond gedrag.

Echter met omgevingsmaatregelen alleen zijn we er in de public health nog niet. Er zijn nog veel vragen over hoe met goed onderbouwde strategieën het gewenste gezondheidsgedrag tot stand moet komen. Op het gebied van roken is bijvoorbeeld gepleit voor het invoeren van angstwekkende sigarettenverpakkingen om een verdere neerwaartse trend van het aantal rokers te bespoedigen. Een dergelijke ogenschijnlijk eenvoudige interventie levert echter niet het gewenste resultaat op. Onderzoek wijst uit dat angstboodschappen niet of zelfs averechts werken als niet tegelijkertijd aan de voorwaarde wordt voldaan van een sterke eigen effectiviteit van de roker om te kunnen stoppen. ${ }^{4,5}$ In het regeerakkoord is er veel aandacht voor sport en bewegen. Het is goed voor de sociale contacten en houdt de mensen fit. Kinderen leren sociale vaardigheden. Door investeren in sport en bewegen, zo lijkt het, krijg je in alle opzichten gezond levende burgers. Het is echter een misverstand dat sport en bewegen automatisch leiden tot algemeen weerbare burgers die zich ook veilig in het verkeer gedragen, niet roken en matig alcohol drinken. Weloverwogen gedragsverande- ringsstrategieën zijn nodig om jong en oud op het spoor te brengen van een gezonde leefstijl.

De public health is de wetenschap en kunde van het scheppen van een gezonde omgeving, het verbeteren van het zorgsysteem en het organiseren van gedragsveranderingsprogramma's. De regering heeft zich voorgenomen om burgers te ondersteunen bij preventie en een gezonde leefstijl. Daarbij hoort ook investeren in een gezonde omgeving en in kennis over hoe je de bevolking aanzet tot gezond gedrag.

\section{Paul Kocken}

\section{LITERATUUR}

1. Bruggen slaan; regeerakkoord VVD - PvdA. Den Haag: VVD PvdA, 2012.

2. Lanting CI, Wouwe K van, Burg I van den, Segaar D, Pal-de Bruin $K$ van der. Roken tijdens de zwangerschap. Trends in de periode 2001-2010. Ned Tijdschr Geneesk 2012;156:A5092.

3. Kocken PL, Eeuwijk J, Kesteren NMC van et al. Promoting the purchase of low-calorie foods from school vending machines: a cluster-randomized controlled study. J School Health 2012;82: 115-22.

4. Peters GY, Ruiter R, Kok G. Threatening communication: a critical re-analysis and revised meta-analytic test of fear appeal theory. Health Psychol Rev 2012; 1-24. DOI:10.1080/ 17437199.2012.70352.

5. Peters GY, Ruiter RAC, Kessels L, Kok G. Angstaanjagende voorlichting: niet effectief, maar desondanks wordt het nog gebruikt. Tijdschr Gezondheidswet 2013;91:15-18. 